\title{
Glacier-climate investigations in 1984 at Qamanârssûp sermia, West Greenland
}

\author{
Roger J. Braithwaite
}

As part of the GGU programme of hydropower investigations in West Greenland, glaciological and climatological measurements were continued at Qamanârssûp sermia (inventory number $1 \mathrm{CH} 21002$ ) in 1984 . The station was first established in late summer 1979 so that records for five complete summers 1980-1984 are now available. Brief reports on the work have been given by Olesen (1981), Olesen \& Braithwaite (1982), Braithwaite (1983a), and Braithwaite (1984). More detailed analyses and presentations of data can be found in Braithwaite \& Olesen (1982) and Braithwaite (1983b) for the years 1979-1981 and 1982 respectively. A similar report for 1983-1984 is planned. As a supplement to the routine programme of measurements by GGU, mapping and survey work have also been carried out by Aarhus University, e.g. a $1: 10000$ map of the lower part of the glacier by Knudsen \& Møller (1982) and an analysis of ice velocity variations by Andreasen (1982). A sketch map of Qamanârssûp sermia, showing locations of stakes and survey points, is given by Braithwaite (1983a).

\section{Field work in 1984}

The field programme for 1984 was generally the same as in previous years. However, some unpleasant experiences with crevasses in spring 1983 lead to the decision to discontinue the measurement of winter accumulation by snow scooter traverse. The accumulation measurements in 1984 were made by helicopter and it is planned to continue this in future years. This allows the start of the fieldwork to be moved by about two weeks to late May, preferably timed so that complete climatological measurements can be made for June, which gives some financial saving.

Measurements of transient balances were made at various times during the season within the network of stakes which extends up to an elevation of $1500 \mathrm{~m}$ a.s.l. Ablation readings were made at the three '751' stakes near to base camp on an almost daily basis. All stake positions were determined by triangulation from fixed points on bedrock in late June, and again in mid-August. Full climatological observations were made at the base camp between 4th June and 31st August, supplemented by a thermohygrograph station at Stake 075 in the middle of the glacier at roughly the same elevation as the base camp. A further thermohygrograph station was established on a nunatak close to the climatic firn line at about 1500 $\mathrm{m}$. An automatic climate station has also been operated by the Greenland Technical Organization (GTO) at the base camp in cooperation with GGU since the beginning of the project (Braithwaite, 1983c). The most recent records for this station, i.e. for September 1983 to August 1984, are awaiting analysis (T. Thomsen, GTO, personal communication).

Several new features were introduced into the field programme for 1984. For example, some stakes were drilled into the Inland Ice to the south of Qamanârssûp sermia at Isortuarssûp tasia where the GTO are making hydropower investigations. A new type of port- 
Table 5. Climatological data summary for base camp, Qamanârssûp sermia 19801984

\begin{tabular}{|c|c|c|c|c|}
\hline & June & July & August & Summer \\
\hline \multicolumn{5}{|c|}{ Monthly mean temperature $\left({ }^{\circ} \mathrm{C}\right)$} \\
\hline $\begin{array}{l}1980 \\
1981 \\
1982 \\
1983 \\
1984 \\
\text { Mean }\end{array}$ & $\begin{array}{l}4.7^{\mathrm{a}} \\
5.2^{\mathrm{b}} \\
4.9 \\
3.3 \\
4.4^{\mathrm{c}} \\
4.5^{2}\end{array}$ & $\begin{array}{l}6.6 \\
7.5 \\
6.0 \\
5.2 \\
7.5 \\
6.6\end{array}$ & $\begin{array}{l}5.5 \\
3.9 \\
4.3 \\
1.8 \\
4.7^{\mathrm{d}} \\
4.0\end{array}$ & $\begin{array}{l}5.6 \\
5.5 \\
5.1 \\
3.4 \\
5.5 \\
5.0\end{array}$ \\
\hline \multicolumn{5}{|c|}{ Monthly precipitation ( $\mathrm{mm}$ ) } \\
\hline $\begin{array}{l}1980 \\
1981 \\
1982 \\
1983 \\
1984 \\
\text { Mean }\end{array}$ & $\begin{array}{rl}20 & \mathrm{a} \\
27 & \mathrm{~b} \\
8 & \\
101 & \\
16 & \mathrm{c} \\
34 & \end{array}$ & $\begin{array}{r}61 \\
148 \\
111 \\
102 \\
77 \\
100\end{array}$ & $\begin{array}{r}64 \\
81 \\
55 \\
190 \\
139 \\
106\end{array}$ & $\begin{array}{l}145 \\
256 \\
174 \\
393 \\
232 \\
240\end{array}$ \\
\hline \multicolumn{5}{|c|}{ Global radiation $\left(\mathrm{MJ} \mathrm{m}^{-2}\right)$} \\
\hline $\begin{array}{l}1980 \\
1981 \\
1982 \\
1983 \\
1984 \\
\text { Mean }\end{array}$ & $\begin{array}{c}605 \\
633 \\
711 \\
582 \\
(702) \\
647\end{array}$ & $\begin{array}{l}624 \\
577 \\
493 \\
487 \\
543 \\
545\end{array}$ & $\begin{array}{c}584 \\
391 \\
471 \\
379 \\
(291) \\
423\end{array}$ & $\begin{array}{l}1813 \\
1601 \\
1675 \\
1448 \\
1536 \\
1615\end{array}$ \\
\hline
\end{tabular}

\begin{tabular}{ll}
\hline $\mathrm{a}$ & $=$ based on 26 days of record \\
$\mathrm{b}$ & $=$ based on 29 days of record \\
$\mathrm{c}$ & $=$ based on 27 days of record \\
$\mathrm{d}$ & $=$ based on 30 days of record \\
$\mathrm{e}$ & $=$ calculated from sunshine duration \\
$0 \quad$ & $=$ adjusted to full month
\end{tabular}

able automatic climate station was also installed on one of the stakes by GTO. If successful, the measurements will provide a means of testing methods for transferring data from Qamanârssûp sermia to areas of interest in connection with hydropower. Another project involving the recording of wind and temperature profiles for the computation of the sensible heat flux, together with measurements of net radiation, was carried out at stake 007 on Qamanârssûp sermia by Aarhus University (Lector T. Knudsen and O. Bendixen).

Table 6. Ablation at the three '751' stakes, Qamanârssûp sermia 1980-1984

\begin{tabular}{lcccccc}
\hline & June & July & August & Sum & Year & Sum/Year \% \\
\hline 1980 & $(0.91)$ & 1.34 & 1.01 & 3.26 & 4.09 & 80 \\
1981 & $(1.16)$ & 1.86 & 0.80 & 3.82 & 4.69 & 81 \\
1982 & 1.07 & 1.58 & 1.16 & 3.81 & 4.66 & 82 \\
1983 & 0.89 & 1.46 & 0.57 & 2.92 & 3.74 & 78 \\
1984 & $(0.99)$ & 1.70 & $(1.10)$ & 3.80 & 4.26 & 89 \\
Mean & 1.00 & 1.59 & 0.93 & 3.52 & 4.29 & 82 \\
\hline
\end{tabular}

$O=$ adjusted to full month.

Ablation for the three summer months as well as for the year (1st September to 31 st August).

Units are metres of water. 
Table 7. Annual balances for Qamanârssûp sermia for the five years 1979/80 to 1983/84

\begin{tabular}{|c|c|c|c|c|c|c|}
\hline Stake & Elevation & $1979 / 80$ & $1980 / 81$ & $1981 / 82$ & $1982 / 83$ & $1983 / 84$ \\
\hline $\begin{array}{l}001 \\
002 \\
003 \\
004 \\
005 \\
006 \\
007 \\
075 \\
751 \\
008 \\
009 \\
091 \\
093 \\
010 \\
011 \\
012 \\
013 \\
015 \\
016 \mathrm{~b} \\
016 \mathrm{a}\end{array}$ & $\begin{array}{r}110 \\
190 \\
320 \\
370 \\
490 \\
580 \\
680 \\
760 \\
790 \\
790 \\
910 \\
880 \\
940 \\
930 \\
1000 \\
1090 \\
1200 \\
1410 \\
c .1470 \\
c .1520\end{array}$ & $\begin{array}{l}-3.49 \\
-4.09 \\
-3.05 \\
-2.33 \\
-2.75 \\
-2.50 \\
-2.34 \\
-1.98\end{array}$ & $\begin{array}{l}-5.28 \\
-4.50 \\
-5.92 \\
-6.33 \\
-4.63 \\
-3.92 \\
-5.18 \\
-4.11 \\
-4.69 \\
-4.23 \\
-2.49 \\
-3.87 \\
-2.03 \\
-1.89 \\
-1.38 \\
-1.96 \\
-0.41 \\
-0.47\end{array}$ & $\begin{array}{l}-4.90 \\
-4.89 \\
-5.44 \\
-5.26 \\
-3.74 \\
-3.56 \\
-4.57 \\
-4.66 \\
-5.14 \\
-2.19 \\
-3.43 \\
-1.78 \\
-2.11 \\
-1.57 \\
-1.62 \\
-0.31 \\
-0.33 \\
(+0.7)\end{array}$ & $\begin{array}{l}-4.69 \\
-4.28 \\
-4.87 \\
-4.68 \\
-3.36 \\
-2.71 \\
-3.32 \\
-3.74 \\
-2.52 \\
-2.22 \\
-2.67 \\
-0.78 \\
-0.67 \\
-0.61 \\
-0.87 \\
(+0.8) \\
<--0.7 \\
<--(+0.5\end{array}$ & $\begin{array}{l}-4.64 \\
-4.31 \\
-4.45 \\
-4.63 \\
-3.65 \\
-3.23 \\
-3.09 \\
-4.26 \\
-3.18 \\
-1.97 \\
-1.89 \\
-0.77 \\
-0.93 \\
-1.29 \\
(+0.4) \\
)-->\end{array}$ \\
\hline
\end{tabular}

$0=$ figures of doubtful reliability.

The measurement year is from 1st September to 31 st August.

Units are metres of water.

When the field party arrived in the area in early June it appeared that there had been more snowfall in the winter of 1983-1984 than usual. The summer was relatively warm, although August was especially wet and cloudy. The equilibrium line was, however, relatively low for the second year running, i.e. below $1200 \mathrm{~m}$. When the field party was evacuated at the end of August it was noticed that snowlines on local glaciers in Godthåbsfjord were also low, i.e. with only about 25 per cent exposure of ice. This probably reflects the influence of a winter with greater than usual precipitation, possibly combined with greater cold, rather than lower summer ablation which was fairly normal at Qamanârssûp sermia.

\section{Summary of five years of measurements}

Some of the more important results from the work at Qamanârssûp sermia are given by Braithwaite (1984) based upon four years of measurement. The latest results for 1984 will naturally lead to some quantitative changes in previous findings but do not appear to contradict them seriously. A summary of monthly statistics for air temperature, precipitation, and global radiation at the base camp is given in Table 5 while ablation at the '751' stake, close to the base camp, is given in Table 6. The data illustrate the fact that wide variations can occur so that glacier-climate studies must be based upon at least a few years of data, although the optimum period of record is still not clear.

Highest temperatures occur in July with lowest temperatures in August. Monthly ablation follows the same pattern whilst the largest amounts of global radiation come in June. A 
study of the relations between ablation, air temperature, and global radiation show a strong correlation between ablation and temperature, and only a weak correlation between ablation and global radiation although it is estimated that net radiation is the major source of ablation energy at Qamanârssûp sermia. This is in broad agreement with the results of Braithwaite (1981) from Arctic Canada. However, the degree-day factor, linking ablation to temperature, is significantly higher than previously assumed by Braithwaite (1980), i.e. 7.3 \pm 0.8 compared to the earlier value of $6.3 \pm 1.1 \mathrm{~kg} \mathrm{~m}^{-2} \mathrm{~d}^{-1} \mathrm{deg}^{-1}$.

Annual balances at all stakes, essentially covering the ablation area, are given in Table 7 . The measurement year is 1st September to 31st August. The last stake readings in the field season are actually made over a few days from late August to early September but the readings are adjusted to fit the chosen measurement year with the help of the daily readings of the '751' stakes. The fixed-date year does not exactly fit the natural, or hydrological, year as some ablation can still occur in September, i.e. as a continuation of the summer ablation which is counted in the annual balance for the following measurement year. The use of a fixed-date year is however more practical both from scientific and administrative considerations. From the detailed measurements at the ' 751 ' stakes, it appears that 80 to 90 per cent of the annual ablation occurs in the main field season of June to August with relatively little ablation in September and May.

The annual balances generally increase with elevation although they are far from following a linear relation as in some other areas. For example, the lowest (negative) balances occur around stakes 003 and 004 rather than on the lowest part of the glacier around stakes 001 and 002 . Further, there is an elevation range of about $200 \mathrm{~m}$ from stake 006 to 008 where the balance is rather constant on average. A study of the year-to-year and stake-to-stake variations in the annual balances has been made, based upon a linear model proposed by Lliboutry (1974). Briefly, the results show that the spatial pattern of variations is repeated from year to year although it is shifted up and down according to year-to-year fluctuation in climate. This fluctuation has a standard deviation of $\pm 0.52 \mathrm{~m}$ water. An analysis of variance of the annual balances at the three ' 751 ' stakes, which are located within a few metres of each other, shows that the random error in annual balance measurements is of the order of \pm 0.23 $\mathrm{m}$ water. This represents the highest level of accuracy which can be achieved with glacier-climate models.

\section{Outlook}

Studies should be continued at Qamanârssûp sermia to confirm, and extend, the results. However, in the future more emphasis must be placed upon improving the measurements of annual balance in the highest part of the area, especially around and above the equilibrium line. Measurements at a local glacier in Buksefjorden and on the Inland Ice south of Qamanârssûp sermia, near Isortuarssûp tasia, will be reinforced to test methods of transferring results from Qamanârssûp sermia to other areas.

\section{References}

Andreasen, J. O. 1982: Overfladehastigheden på Qamanârssûp sermia 1980-1981. Grønlands geol. Unders., Gletscher-hydrol. Meddr 82/4, 27-42. 
Braithwaite, R. J. 1980: Regional modelling of ablation in West Greenland. Rapp. Grønlands geol. Unders. 98, 20 pp.

Braithwaite, R. J. 1981: On glacier energy balance, ablation, and air temperature. J. Glaciol. 27, 381391.

Braithwaite, R. J. 1983a: Glaciological and climatological investigations at Qamanârssûp sermia, West Greenland. Rapp. Grønlands geol. Unders. 115, 111-114.

Braithwaite, R. J. 1983b: Glaciological investigations at Qamanârssûp sermia, interim report 1982 and appendix tables. Grønlands geol. Unders., Gletscher-hydrol. Meddr 83/4, 49 pp.

Braithwaite, R. J. 1983c: Comparisons between automatic and manual climate stations at Qamanârssûp sermia. Grønlands geol. Unders., Gletscher-hydrol. Meddr 83/5, $17 \mathrm{pp.}$

Braithwaite, R. J. 1984: Glaciological and climatological investigations at Qamanârssûp sermia, West Greenland. Rapp. Grønlands geol. Unders. 120, 109-112.

Braithwaite, R. J. \& Olesen, O. B. 1982: Glaciological investigations at Qamanârssûp sermia. Field report 1979-1981 and appendix tables. Grønlands geol. Unders., Gletscher-hydrol. Meddr 82/2, 58 pp.

Knudsen, N. T. \& Møller, J. T. 1982: Photogrammetric survey of Qamanârssûp sermia. Grønlands geol. Unders., Gletscher-hydrol. Meddr 82/4, 1-26.

Lliboutry, L. 1974: Multivariate statistical analysis of glacier annual balances. J. Glaciol. 13, 371-392.

Olesen, O. B. 1981: Glaciological investigations at Qamanârssûp sermia, West Greenland. Rapp. Grønlands geol. Unders. 105, 60-61.

Olesen, O. B. \& Braithwaite, R. J. 1982: Glaciological investigations at Qamanârssûp sermia, West Greenland. Rapp. Grønlands geol. Unders. 110, 88-90.

\section{Determination of ice thickness by magnetic methods at Nordbogletscher, South Greenland}

\section{Leif Thorning}

The topographic relief hidden under glaciers and the Inland Ice plays an important role in the study of ice dynamics, and several methods have been applied to map the subglacial surface of the Inland Ice in areas of interest for hydropower investigations. Radar-echo soundings or electromagnetic reflection methods (EMR) have often given good results, but have largely failed over the western rim of the ice cap, where inhomogenities in the form of melted and refrozen layers, water bodies, and cracks in the ice scatter the radar wave to such an extent that no useful echo is returned. In the summer of 1984 the author was in South Greenland for other purposes (Thorning \& Boserup, this report), and it was decided to attempt to determine the ice thickness by magnetic profiling on the ice surface. Magnetic field measurements are not affected by the physical properties and structure of the ice, and thus it should theoretically be possible to obtain results near the rim of the ice cap, where the EMR method has failed. Whether results could be obtained would depend on limiting factors such as the magnetic properties of the underlying rocks, instrument capabilities, sensitivity of correction and modelling methods, and the general ambiguity of potential field methods.

The field work reported here was a pilot study of the application of magnetic methods to 